\title{
In vitro behaviour of Aspasia variegata, an epiphytic orchid from the Brazilian Cerrado
}

\author{
Comportamento in vitro de Aspasia variegata, uma orquídea epífita do cerrado brasileiro
}

\begin{abstract}
Vespasiano Borges de Paiva Neto ${ }^{\mathrm{I}}$ Guilherme de Oliveira Campos ${ }^{\mathrm{I}}$ Amanda Galdi Boaretto ${ }^{\mathrm{I}}$ Monica Cristina Rezende Zuffo ${ }^{\mathrm{I}}$ Mateus de Aguiar Torrezan ${ }^{\mathrm{I}}$ Jamile Benetão $^{\mathrm{I}}$
\end{abstract}

\section{ABSTRACT}

Aspasia variegata occurs naturally in the savanna of the Mato Grosso do Sul State, Brazil and it has been widely collected for its beautiful flowers. Additionally, its habitat has been greatly reduced and little or no investigation of its spread has been performed. Aiming to establish a protocol to obtain seedlings of the orchid A. variegata, different compositions of culture medium were tested to identify which one provided better in vitro growth and development and to assess the influence of these media in seedling acclimatisation. Thus, seeds obtained from mature capsules were inoculated in Knudson culture medium for 120 days until the protocorm stage. They were transferred to different culture media formulations, including MS and Knudson with half or full formulation, and 3.0 and $6.0 \mathrm{~g} \mathrm{~L}^{-1}$ activated charcoal were added to them or not. After 180 days of protocorm inoculation, seedlings were evaluated for length of roots and shoots, number of roots and leaves, and chlorophyll contents. After that, seedlings were transferred to trays containing a mixture of Plantmax ${ }^{\circledR}$ and coconut fibre (1:1) for acclimatisation. Best results for the in vitro growth of A. variegata were obtained with the use of MS medium supplemented with $6.0 \mathrm{~g} \mathrm{~L}^{-1}$ activated charcoal. Higher levels of chlorophyll were obtained, however, in treatments containing MS salts without activated charcoal presence, and lower levels in media containing Knudson salts with the presence of activated charcoal. The seedlings originated by higher chlorophyll levels during in vitro cultivation presented the highest survival rates and better development in the acclimatisation phase.

Key words: orchidaceae, activated charcoal, chlorophyll content, acclimatisation.

\section{RESUMO}

A orquídea Aspasia variegata ocorre naturalmente no Cerrado Sul-Matogrossense, e tem sido bastante coletada de seu habitat, devido à beleza de suas flores. Adicionalmente, sua área de ocorrência tem sido bastante reduzida e pouco ou nenhum estudo visando a sua multiplicação tem sido realizado. Objetivando estabelecer protocolo para obtenção de mudas de A. variegata, diferentes composições de meio de cultivo foram testadas para observar aquela que propicia melhores condições para crescimento e desenvolvimento dos protocormos in vitro e ainda a influência desses meios na fase de aclimatização das mudas. Para tal, foram utilizadas cápsulas maduras para obtenção das sementes, as quais foram inoculadas em meio de cultivo básico Knudson por 120 dias até o desenvolvimento de protocormos. Estes foram então transferidos para diferentes formulações dos meios de cultivo MS e Knudson, variando a concentração de sais e de carvão ativado (0; 3,0 e 6,0g $\left.\mathrm{L}^{-1}\right)$. Após 180 dias da inoculação dos protocormos, foram realizadas avaliações referentes ao comprimento da maior raiz e da parte aérea, número de raízes e folhas, e quantificados os teores de clorofila. Em seguida, as mudas foram transferidas para bandejas contendo uma mistura de Plantmax ${ }^{\circledR}$ e Fibra de Coco (1:1) para aclimatização. Melhores resultados para o crescimento in vitro de A. variegata foram obtidos com a utilização do meio de cultura MS, acrescido de 6,0g $\mathrm{L}^{-1}$ de carvão ativado. No entanto, os maiores níveis de clorofila foram obtidos nos tratamentos contendo sais MS desprovidos de carvão ativado, e os menores nos meios contendo sais Knudson providos com carvão ativado. As plantas oriundas dos tratamentos com maiores teores de clorofila total durante a fase in vitro obtiveram as maiores taxas de sobrevivência e melhor desenvolvimento na fase de aclimatização.

Palavras-chave: orchidaceae, carvão ativado, clorofila, aclimatização.

\section{INTRODUCTION}

The Orchidaceae family has approximately 35,000 species and several hybrids, being one of the largest families in the plant kingdom (SUTTLEWORTH et al., 1994). In Brazil, around 2.400 species of orchids are known, which represents approximately $10 \%$ of all the species in this family

\footnotetext{
'Universidade Federal de Mato Grosso do Sul (UFMS), 79560-000, Chapadão do Sul, MS, Brasil. E-mail: vespasiano.neto@ufms.br.

*Autor para correspondência. 
(BARROS, 1996). Aspasia Lindl. is a plant genus first described by John Lindley in 1832 in The genera and species of orchidaceous plants. According to ULLMANN (2007) this genus has around eight epiphyte species, comprising medium-sized plants with long floral stems. Aspasia variegata Lindl. is found in Colombia, Venezuela, Trinidad, Guiana, Suriname and Brazil (WILLIAMS, 1974). Although the cultivation of exotic orchids has helped to make Brazil internationally famous, they have been obtained, almost without exception, through the predatory exploration of tropical forests (KÄMPF, 2000). The uncontrolled exploitation of these natural resources has resulted in the degradation of areas in almost all Brazilian territory (FERREIRA, 2000).

The orchid $A$. variegata is an epiphytic species of the Brazilian savanna which is found on tree species present in riparian forests very near the watercourse. This ambience provides good conditions for their germination and development. The species is prized by collectors because of its high ornamental value (Figure $1 \mathrm{~A}$ ), and unfortunately its populations have decreased drastically over the last few years because of depredation and the destruction of their habitats. In addition, the specialist literature has no information about in vitro multiplication of A. variegata. A possible consequence is the future extinction of the species, and provides justification for the propagation and conservation of this valuable germplasm. MAHENDRAN et al. (2013) says that orchids in the wild are endangered as a consequence of environmental disruption, succession of natural habitats and over-exploitation for horticultural purposes. In situ conservation of dwindling populations of endangered orchid species is very difficult because of their slow growth and poor seed germination.

Consequently, in vitro culture can be an interesting technique for both propagation and germplasm conservation of this species. Successful in vitro orchid propagation, however, is influenced by many factors such as plant genotypes, several factors involving media composition (GNASEKARAN et al., 2012) and activated charcoal (THOMAS, 2008).

The cultivation medium used in propagation is a determining factor for the success of the in vitro cultivation of orchids. The MS culture medium (MURASHIGE \& SKOOG, 1962) is the one used most frequently in in vitro propagation, but several research studies on orchids use a modified basic Knudson medium (ARDITTI \& ERNST, 1993). Among the additives tested in culture media, activated charcoal has been widely used. Studies have reported, however, that the concentration of salts in the culture medium directly influences the growth of in vitro orchids, whether by the lack or by the excess thereof(PARK et al., 2004; FIGUEIREDO et al., 2007; STANCATO et al., 2008). Furthermore, another element that requires serious attention is the acclimatisation phase of the seedlings, because the anatomical and physiological aspects of vitroplants have to be adequate for new ex vitro ambient conditions that differ from in vitro conditions in all aspects. Therefore, for the purpose of obtaining an initial efficient propagation method, we decided to research the effect of different formulations of semi-solid media with and without the addition of activated charcoal on in vitro development of A.variegata seedlings and its importance in the acclimatisation phase.

\section{MATERIALS AND METHODS}

Aspasia variegata protocorms obtained from germinated seeds were transferred to glass flasks $(250 \mathrm{~mL})$ containing $40 \mathrm{ml}$ of Knudson culture medium with $6.0 \mathrm{~g} \mathrm{~L}^{-1}$ agar and $20.0 \mathrm{~g} \mathrm{~L}^{-1}$ sucrose, and

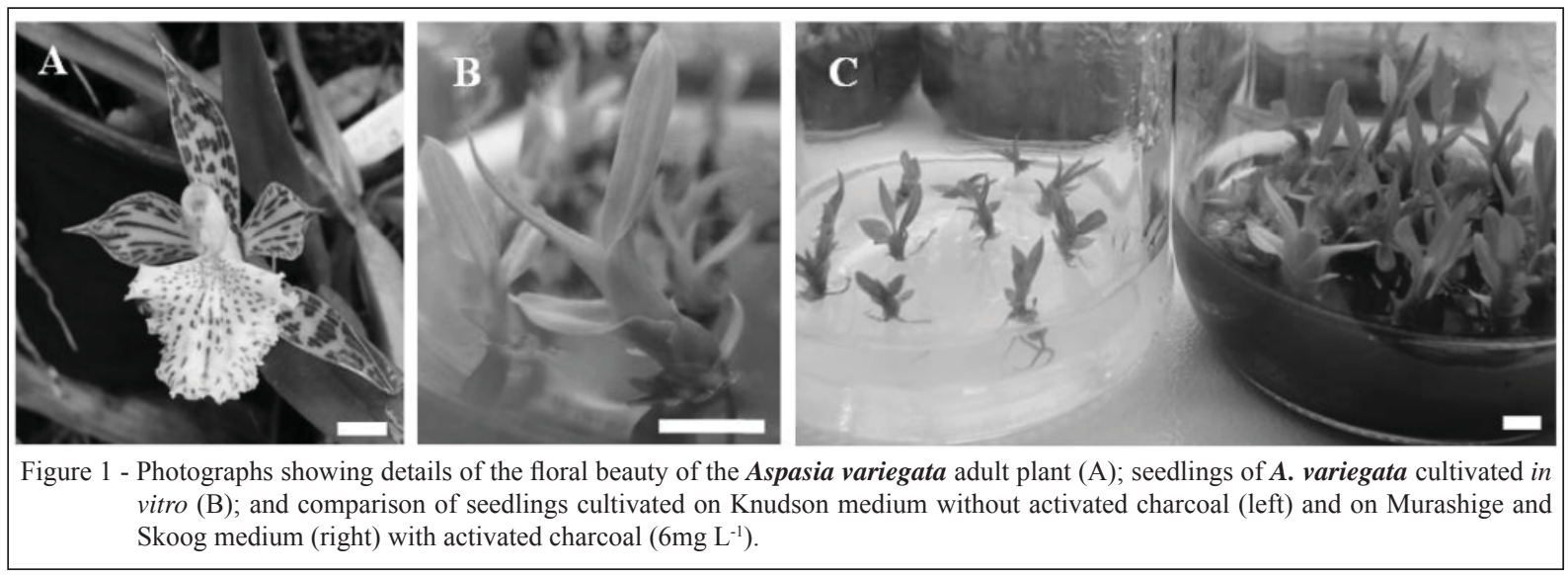

Ciência Rural, v.43, n.12, dez, 2013. 
MS medium (MURASHIGE \& SKOOG, 1962) with $6.0 \mathrm{~g} \mathrm{~L}^{-1}$ agar and $30.0 \mathrm{~g} \mathrm{~L}^{-1}$ sucrose. All the media for the in vitro experiments had $0.1 \mathrm{~g} \mathrm{~L}^{-1}$ inositol, with and without activated charcoal, and $\mathrm{pH} 5.8 \pm 0.1$ adjusted before the autoclave process $\left(121^{\circ} \mathrm{C}\right.$ and $104 \mathrm{KPa}$ for 20 minutes). To maximise the in vitro development of the A. variegata protocorms, different formulations of the MS and Knudson media were tested, resulting in the following treatments: T1 - Total MS, T2 - MS with half the salts, T3 - Total MS supplemented with activated charcoal (3.0g L $\left.\mathrm{L}^{-1}\right)$, T4 - MS supplemented with activated charcoal $\left(6.0 \mathrm{~g} \mathrm{~L}^{-1}\right), \mathrm{T} 5$ - Total Knudson, T6 - Knudson with half the salts, T7 - Total Knudson supplemented with activated charcoal $\left(3.0 \mathrm{~g} \mathrm{~L}^{-1}\right), \mathrm{T} 8$ Total Knudson supplemented with activated charcoal (6.0 $\left.\mathrm{g} \mathrm{L}^{-1}\right)$.

The experimental design used was entirely randomised and comprised eight treatments with ten replications each. Each replication comprised a glass flask containing 15 protocorms. All of the in vitro experiments were performed in a plant growth room with a 16-hour photoperiod and irradiation of $36 \mu \mathrm{mol} \mathrm{m} \mathrm{m}^{-2} \mathrm{~s}^{-1}$ and temperature of $27 \pm 2^{\circ} \mathrm{C}$. The protocorm conversion was evaluated at 30 and 60 days after inoculation, counting the seedlings obtained from protocorm conversion. Cultures were then co-cultivated at 90 days and analysed at 180 days after protocorm innoculation, when the in vitro experiment was finished. To this end, vitroplants from five replications (flasks) of each treatment were used to measure the length of the main root and aerial part, the number of leaves and roots, and the aerial part of these vitroplants was used to quantify the levels of chlorophylls a, b, and total. Three samples of $0.250 \mathrm{~g}$ of fresh plant matter were weighed for each treatment, mashed in $8 \mathrm{ml}$ of acetone (P.A., Synth). The samples were centrifuged (3500rpm; $2 \mathrm{~min})$. The supernatant was used to obtain the absorbance (\%) in the wavelength bands of 645 and $663 \mathrm{~nm}$ with a spectrophotometer. The chlorophyll contents were determined by the Arnon method (ARNON, 1949).

The seedlings of the remaining flasks (05) of each treatment were used to evaluate the acclimatisation phase. Initially, the length of the aerial part and main root was measured with a ruler, and then the number of roots and leaves were counted. Immediately, the vitroplants were placed in expansible polystyrene trays measuring $18 \mathrm{~cm}$ width $\mathrm{x} 23 \mathrm{~cm}$ length $\mathrm{x} 5 \mathrm{~cm}$ height and containing five holes on the bottom holding a mixture of Plantmax ${ }^{\circledR}$ and coconut fibre $(1: 1)$. The trays were placed on benches and kept for 90 days in a greenhouse with an intermittent irrigation system comprised of microsprinklers activated by a timer with two daily irrigation cycles of two minutes each. The plants received leaf composting (NIPOKAN ${ }^{\circledR}$ ) at weekly intervals. After the acclimatisation period, the plants were evaluated in terms of the number of roots, height of the aerial part $(\mathrm{cm})$, number of leaves, size of the main root (cm) and total fresh weight $(\mathrm{mg})$.

All data were subjected to statistical analysis with SISVAR software (FERREIRA, 2000), and the mean values were compared by the Tukey test at $5 \%$ probability.

\section{RESULTS AND DISCUSSION}

The total experiment lasted for 12 months, from seed inoculation to acclimatisation. The differentiation of protocorms of A. variegata, that is, the beginning of formation of leaves and roots was satisfactory in all of the tested media. However, the media containing the Knudson salts having a slight numerical advantage in relation to those with the MS salts after the first 30 days of inoculation, when a statistical difference was detected in the differentiation of protocorms in the medium with half Knudson salts $(94.16 \%)$ in relation to the medium with MS salts with $3.0 \mathrm{~g} \mathrm{~L}^{-1}$ of activated charcoal $(78.80 \%)$. Additionally no statistical difference was detected after 60 days (data not shown). This initial difference in response may be related to the low nutrient requirement in the initial germination steps in orchids. MAHENDRAN et al. (2013) affirm that the nutrient regime for orchid culture is species-specific and no single culture medium is universally applicable to all orchid species. They found great differences in Cymbidium bicolor in vitro seed germination when they compared four culture media, varying from $96.6 \%$ (Lindemann medium) to $62.7 \%$ (Knudson C medium) in total seed germination.

In relation to the parameters evaluated in the seedlings obtained from protocorm conversion, there was a significant effect of the culture media (Tables 1 and 2). The length of the largest root was improved when the culture medium contained MS salts, independently of its concentration (half or total salts) and activated charcoal presence. The worst performances for this parameter occurred in the media containing Knudson salts. It is worth mentioning that the Knudson medium displays considerable differences in relation to MS medium, such as lower nutritional concentration. The beneficial effect of activated charcoal on seedling development was more evident when it was added to MS medium. Other authors 
Table 1 - Development analysis of Aspasia variegata seedlings cultivated in vitro for 180 days in different compositions of Murashige and Skoog (MS) and Knudson (KC) media with and without activated charcoal (AC). Chapadão do Sul, Mato Grosso do Sul, 2011.

\begin{tabular}{lllll}
\hline Medium & Root & Aerial part & Roots & Leaves \\
\hline $\mathrm{MS}$ & $0.703 \mathrm{ab}$ & $1.592 \mathrm{c}$ & $4.183 \mathrm{bc}$ & $6.350 \mathrm{c}$ \\
$\mathrm{MS} / 2$ & $0.737 \mathrm{a}$ & $1.463 \mathrm{c}$ & $4.617 \mathrm{~b}$ & $6.467 \mathrm{c}$ \\
$\mathrm{MS}+3 \mathrm{~g} \mathrm{~L}^{-1} \mathrm{AC}$ & $0.630 \mathrm{abc}$ & $2.351 \mathrm{ab}$ & $5.299 \mathrm{ab}$ & $6.650 \mathrm{bc}$ \\
$\mathrm{MS}+6 \mathrm{~g} \mathrm{~L}^{-1} \mathrm{AC}$ & $0.723 \mathrm{ab}$ & $2.831 \mathrm{a}$ & $6.817 \mathrm{a}$ & $6.068 \mathrm{a}$ \\
$\mathrm{KC}$ & $0.483 \mathrm{~cd}$ & $1.443 \mathrm{c}$ & $5.400 \mathrm{ab}$ & $5.383 \mathrm{c}$ \\
$\mathrm{KC} / 2$ & $0.400 \mathrm{~d}$ & $1.098 \mathrm{c}$ & $4.067 \mathrm{bc}$ & $5.650 \mathrm{c}$ \\
$\mathrm{KC}+3 \mathrm{~g} \mathrm{~L}^{-1} \mathrm{AC}$ & $0.520 \mathrm{bcd}$ & $1.760 \mathrm{bc}$ & $5.633 \mathrm{ab}$ & $7.917 \mathrm{a}$ \\
$\mathrm{KC}+6 \mathrm{~g} \mathrm{~L}^{-1} \mathrm{AC}$ & $0.428 \mathrm{~cd}$ & $1.172 \mathrm{c}$ & $3.000 \mathrm{c}$ & $6.983 \mathrm{abc}$ \\
$\mathrm{CV}(\%)$ & 17.34 & 19.31 & 16.16 & 9.63 \\
\hline
\end{tabular}

Means followed by the same letter in the same column do not differ from each other by Tukey test at $5 \%$ significance.

also found a positive relationship between activated charcoal levels and orchid root growth; for example, Laelia tenebrosa showed linear root growth in relation to concentrations of charcoal (ARAUJO et al., 2006). These authors also found, however, that the media containing the highest salt concentrations needed a greater amount of activated charcoal to obtain a similar result. The presence of activated charcoal reduces light penetration to the roots, thus providing suitable conditions for root growth, and provides a favourable environment for accumulated photoprotection of auxin or co-factors (THOMAS, 2008). Some species of orchids, however, have no influence of the activated charcoal in root growth. CHAPLA et al. (2009) observed that the presence of activated charcoal in culture medium inhibited the growth of the primary root of Miltonia flavescens Lindl., which presented better development in charcoal-free medium. These different responses demonstrate the importance of studying the action of additives in the development of different species of orchids.

The length of the aerial part benefited from activated charcoal presence in the MS medium, the best results being obtained with the addition of $6.0 \mathrm{~g}$ $\mathrm{L}^{-1}$ (Table 1), and consequently the lowest lengths of the aerial parts were obtained in the seedlings from the media containing MS salts without charcoal and from the media containing Knudson salts (Figure 1). Therefore, in general activated charcoal presence was beneficial for the development of the aerial part of the seedlings. PRIZÃO et al. (2012) confirmed that the presence of charcoal was particularly important in inducing roots and sprouts in the double hybrid of orchid 'BLC Pastoral Innocence' when inoculated in medium without growth regulator.

The number of leaves and roots benefited from activated charcoal presence in the MS and Knudson media, the best responses being obtained

Table 2 - Mean levels of chlorophylls $a, b$ and total ( $\mu \mathrm{g} \mathrm{g}^{-1}$ fresh matter) in leaves of Aspasia variegata cultivated in vitro in different compositions of Murashige and Skoog (MS) and Knudson (KC) media with or without activated charcoal (AC). Chapadão do Sul, Mato Grosso do Sul, 2011.

\begin{tabular}{lccc}
\hline Treatment & Chlorophyll $a$ & Chlorophyll $b$ & Total chlorophyll \\
\hline $\mathrm{MS}$ & $20.609 \mathrm{a}$ & $14.434 \mathrm{a}$ & $35.044 \mathrm{a}$ \\
$\mathrm{MS} / 2$ & $21.204 \mathrm{a}$ & $13.870 \mathrm{a}$ & $35.074 \mathrm{a}$ \\
$\mathrm{MS}+3 \mathrm{~g} \mathrm{~L}^{-1} \mathrm{AC}$ & $17.595 \mathrm{ab}$ & $11.388 \mathrm{a}$ & $28.983 \mathrm{a}$ \\
$\mathrm{MS}+6 \mathrm{~g} \mathrm{~L}^{-1} \mathrm{AC}$ & $15.878 \mathrm{~b}$ & $12.738 \mathrm{a}$ & $28.617 \mathrm{a}$ \\
$\mathrm{KC}$ & $18.098 \mathrm{ab}$ & $12.073 \mathrm{a}$ & $30.171 \mathrm{a}$ \\
$\mathrm{KC} / 2$ & $19.888 \mathrm{ab}$ & $12.645 \mathrm{a}$ & $32.283 \mathrm{a}$ \\
$\mathrm{KC}+3 \mathrm{~g} \mathrm{~L}^{-1} \mathrm{AC}$ & $4.672 \mathrm{c}$ & $3.076 \mathrm{~b}$ & $7.748 \mathrm{~b}$ \\
$\mathrm{KC}+6 \mathrm{~g} \mathrm{~L}^{-1} \mathrm{AC}$ & $6.208 \mathrm{c}$ & $4.038 \mathrm{~b}$ & $10.247 \mathrm{~b}$ \\
$\mathrm{CV}(\%)$ & 12.00 & 19.37 & 12.81 \\
\hline
\end{tabular}

Means followed by the same letters in the same column do not differ from each other by Tukey test at $5 \%$ significance.

Ciência Rural, v.43, n.12, dez, 2013. 
with the addition of $6.0 \mathrm{~g} \mathrm{~L}^{-1}$ in the complete MS medium (Table 1), and consequently the lowest number of leaves was obtained in the seedlings from the media without charcoal. This shows that seedlings cultivated in the medium with higher salt availability and charcoal presence benefited in terms of growth parameters. PRIZÃO et al. (2012) confirmed that the use of activated charcoal is useful for root induction in seedlings of Cattleya bicolor.

With regard to the chlorophyll evaluations (Table 2), an expressive and significant reduction was evident in the contents of chlorophylls a, b and total in all seedlings cultivated in the Knudson medium with activated charcoal. In plants cultivated in the medium with MS salts, this reduction was statistically different only for the contents of chlorophyll a. This response seems to be related to the fact that activated charcoal adsorbs a considerable portion of beneficial (e.g. nitrogen) and harmful medium components. Therefore, in general the comparison of chlorophyll contents between seedlings cultivated on MS medium (half or total salts), with or without activated charcoal, shows that chlorophyll is almost the same, perhaps because MS medium is considered as one with a high concentration of slats. Consequently the nutritional components adsorbed by activated charcoal still maintained satisfactory levels of nutrients and we assume that activated charcoal reduces chlorophyll content always that it is on medium composition (Table 3). This was more determinant when seedlings were cultivated on Knudson medium because there is less nitrogen than in MS medium. It is clear, however, that activated charcoal presence further decreased nutrient availability on Knudson medium. All these factors damaged seedling growth and development, resulting in several morphological factors as minor root number and root length in seedlings came from Knudson medium added with activated charcoal, resulting in reduced nitrogen absorption affecting chlorophyll synthesis. GALDIANO JÚNIOR et al. (2012), using MS medium, did not find a great difference in the chlorophyll levels in seedlings of Cattleya loddigesii cultivated in different activated charcoal concentrations, thus corroborating the results we obtained with MS medium.

Sucrose level is another factor that can induce changes in chlorophyll synthesis (DIGNART et al., 2009; GALDIANO JÚNIOR et al., 2013). Several researchers have reported that, for many species, the presence of sucrose in the culture medium is the main reason for reduction in chlorophyll contents and consequently in photosynthesis; low levels of sucrose in the culture medium were correlated to an elevated potential of carbohydrate production by the photosynthetic pathways (ADELBERG et al., 1999; KANECHI et al., 1998). GALDIANO JÚNIOR et al. (2013) compared different sucrose levels in Cattleya loddigesii development and observed that $20 \mathrm{~g} \mathrm{~L}^{-1}$ of sucrose support growth did not affect chlorophyll synthesis. This behaviour was not seen in the present experiment, corroborating observations made by DIGNART et al. (2009) for the orchid Cattleya walqueriana. They did not observe any correlation between the levels of sucrose and the levels of chlorophylls of in vitro plants.

The capacity for survival and development of seedlings during the acclimatisation phase (Table 3) was determined by the plant length during the in vitro cultivation phase (Table 1). Therefore, those seedlings from the Knudson medium supplemented with $3.0 \mathrm{~g} \mathrm{~L}^{-1}$ and $6.0 \mathrm{~g} \mathrm{~L}^{-1}$ of activated charcoal resulted in only $24.0 \%$ and $36.0 \%$ of survival respectively, resulting in higher mortality rates (data not shown), similarly to those seedlings which presented the worst growth parameters (Table 1) and the lowest levels of chlorophyll in vitro (Table 2). The other treatments resulted in mortality rates averaging $15 \%$. Therefore, the size of the aerial part was essential for plant survival, given that the development of algae was for a threat to the survival of the smaller seedlings. The development of algae was related to the variations in atmospheric humidity, leading to eventual humidity in the trays. DORNELES \& TREVELIN (2011), during the acclimatisation of Cattleya intermedia, also observed an intolerance to excessive humidity, whereby some seedlings in sphagnum substrate were lost because of the decomposition of their roots. Thus, observing the growth data of the seedlings after acclimatisation (Table 3), i.e. fresh weight, presence of bud and size of roots and aerial parts, we can confirm that the best performances during this phase were obtained by the seedlings from the media that were more concentrated in salts (MS) and presented higher chlorophyll contents. Therefore, this last in vitro factor is apparently essential for a good performance in the acclimatisation phase. Curiously, seedlings of A. variegata that presented higher growth during the acclimatisation phase were not those that came from MS medium containing activated charcoal, which presented the best behaviour in vitro, but those that came from MS medium (half and total salts) without activated charcoal (Table 3). Nonetheless, survival average $(90 \%)$ did not differ in these treatments during the acclimatisation phase. GALDIANO JÚNIOR et al. (2012) concluded that the use of activated charcoal during in vitro culture provided 
Table 3 - Data related to the size and mean number of roots and aerial part and total fresh weight of in vitro seedlings of Aspasia variegata cultivated in different compositions of Murashige and Skoog (MS) and Knudson (KC) media with or without activated charcoal (AC), and acclimatised in an agricultural oven in coconut powder substrate. Chapadão do Sul, Mato Grosso do Sul, 2011.

\begin{tabular}{|c|c|c|c|c|c|}
\hline \multirow{2}{*}{ Treatment } & \multicolumn{4}{|c|}{ 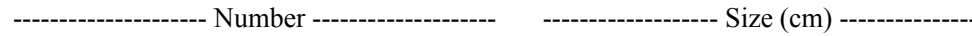 } & \multirow{2}{*}{ Fresh weight $(\mathrm{mg})$} \\
\hline & Roots & Buds & Root & Aerial part & \\
\hline MS & $7.96 \mathrm{ab}$ & $0.54 \mathrm{abc}$ & $5.00 \mathrm{a}$ & $4.50 \mathrm{a}$ & $473.92 \mathrm{a}$ \\
\hline $\mathrm{MS} / 2$ & $7.76 \mathrm{abc}$ & $0.60 \mathrm{ab}$ & $5.04 \mathrm{a}$ & $4.72 \mathrm{a}$ & $561.92 \mathrm{a}$ \\
\hline $\mathrm{MS}+3 \mathrm{~g} \mathrm{~L}^{-1} \mathrm{AC}$ & $6.20 \mathrm{bcd}$ & $0.72 \mathrm{a}$ & $3.32 \mathrm{ab}$ & $2.52 \mathrm{bc}$ & $207.84 \mathrm{bc}$ \\
\hline $\mathrm{MS}+6 \mathrm{~g} \mathrm{~L}^{-1} \mathrm{AC}$ & $5.55 \mathrm{ed}$ & $0.82 \mathrm{a}$ & $4.00 \mathrm{ab}$ & $2.95 \mathrm{~b}$ & $261.23 \mathrm{~b}$ \\
\hline $\mathrm{KC}$ & $3.95 \mathrm{e}$ & $0.24 \mathrm{bc}$ & $1.48 \mathrm{~d}$ & $1.67 \mathrm{~cd}$ & $95.48 \mathrm{c}$ \\
\hline $\mathrm{KC} / 2$ & $8.60 \mathrm{a}$ & $0.68 \mathrm{a}$ & $2.00 \mathrm{~cd}$ & $1.88 \mathrm{~cd}$ & $182.44 \mathrm{bc}$ \\
\hline $\mathrm{KC}+3 \mathrm{~g} \mathrm{~L}^{-1} \mathrm{AC}$ & $6.05 \mathrm{bcd}$ & $0.16 \mathrm{c}$ & $1.53 \mathrm{~d}$ & $1.74 \mathrm{~cd}$ & $117.89 \mathrm{bc}$ \\
\hline $\mathrm{KC}+6 \mathrm{~g} \mathrm{~L}^{-1} \mathrm{AC}$ & $6.00 \mathrm{~cd}$ & $0.13 \mathrm{c}$ & $1.56 \mathrm{~d}$ & $1.50 \mathrm{~d}$ & $83.31 \mathrm{c}$ \\
\hline CV (\%) & 30.96 & 86.98 & 45.50 & 36.77 & 63.08 \\
\hline
\end{tabular}

Means followed by the same letters in the same column do not differ from each other by Tukey test at $5 \%$ significance.

greater development efficiency in terms of both in vitro and ex vitro survival of Cattleya loddigesii.

The transplantation stage continues to be a major bottleneck in the micropropagation of orchids. A substantial number of micropropagated plantlets fail to survive when transferred from in vitro conditions to a greenhouse or field environment, as these have substantially lower relative humidity, and higher and more intense light levels that are stressful for micropropagated plants compared with in vitro conditions (CHUGH et al., 2009).

Some aspects involving nutritional medium composition and activated charcoal's capacity to adsorb nutrients need to be investigated further. Additionally, the control of algae growth during the acclimatisation phase deserves special attention in future $\boldsymbol{A}$. variegata propagation.

\section{CONCLUSION}

MS salts supplemented with activated charcoal were the best medium for the in vitro growth of Aspasia variegata seedlings, which showed high chlorophyll contents during in vitro culture, resulting in high survival rates and better development during the acclimatisation phase. Activated charcoal in combination with Knudson salts resulted in a considerable reduction of seedlings' chlorophyll levels, producing the worst performances in the acclimatisation phase.

\section{ACKNOWLEDGMENTS}

The authors would like to thank Fundação de Apoio ao Desenvolvimento do Ensino (FAPEPE), Ciência e Tecnologia do Estado de Mato Grosso do Sul (FUNDECT) and Conselho
Nacional de Desenvolvimento Científico e Tecnológico (CNPq) for financial support.

\section{REFERENCES}

ADELBERG, J. et al. Photoautotrophic shoot and root development for triploid melon. Plant Cell Tissue and Organ Culture, Amsterdam, v.57, n.2, p.95-104, 1999. Available from: $<$ http://www.springerlink.com/index/jj317796029672g9.pdf>. Acessed: Nov. 23, 2012.

ARAUJO, A.G. et al. Crescimento in vitro de Laelia tenebrosa (Orchidaceae) em diferentes concentrações de sais de Knudson-C e carvão ativado. Plant Cell Culture and Micropropagation, v.2, n.2, p.61-67, 2006. Disponível em: <http://www.abctp.ufla.br/ v2n2.pdf $>$. Acesso em: 16 ago. 2013.

ARDITTI, J.; ERNST, R. Phalaenopsis: micropropagation of orchids. 7.ed. New York, 1993. p.467-520.

ARNON, D.I. Copper enzymes in isolated chloroplasts: polyphenoloxydase in Beta vulgaris. Plant Physiology, Maryland, v.24, n.1, p.1-15, 1949. Available from: <http://www.ncbi.nlm. nih.gov/pmc/articles/PMC437905/pdf/plntphys00263-0011.pdf>. Accessed: Nov. 15, 2012.

BARROS, F. Notas taxonômicas para as espécies brasileiras dos gêneros Epidendrum, Patysteles, Pleurothallis e Scaphyglottis (Orchidaceae). Acta Botanica Brasilica, Feira de Santana, v.10, n.1, p.139-152, 1996. Available from: <http://www.scielo.br/pdf/ abb/v10n1/v10n1a11.pdf>. Accessed: Aug. 15, 2012. doi: <http:// dx.doi.org/10.1590/S0102-33061996000100011>.

CHAPLA, P.I. et al. pH, activated charcoal and gelling agents of the culture medium on the in vitro growth of Miltonia flavescens Lindl. Plant Cell Culture and Micropropagation, Lavras, v.5, n.2, p.87-93, 2009. Available from: < http://abctp.jatai.ufg.br/ pages/30544>. Accessed: May 25, 2013.

CHUGH, S. et al. Micropropagation of orchids: a review on the potential of different explants. Scientia Horticulturae, 
Netherlands, v.22, p.507-520, 2009. Available from: <http:// www.sciencedirect.com/science/article/pii/S0304423809003641>. Accessed: May 25, 2013. doi:10.1016/j.scienta.2009.07.016.

DIGNART, S.L. et al. Luz natural e concentrações de sacarose no cultivo in vitro de Cattleya walkeriana. Ciência e agrotecnologia, Lavras, v.33, n.3, p.780-787, 2009. Available from: <http://www. scielo.br/pdf/cagro/v33n3/a17v33n3.pdf $>$. Accessed:Aug. 15, 2012. doi: <http://dx.doi.org/10.1590/S1413-70542009000300017>.

DORNELES, L.T.; TREVELIN, V. Aclimatização e reintrodução de Cattleya intermedia Graham ex Hook (Orchidaceae) obtidas por propagação in vitro. Iheringia, Porto Alegre, v.66, n.2, p.167174, 2011. Available from: <http://www.fzb.rs.gov.br/publicacoes/ iheringia-botanica/Ih66-2-p167-174.pdf $>$. Accessed: Dec. 15, 2012

FERREIRA, C.A.G. Recuperação de áreas degradadas. Informe Agropecuário, Belo Horizonte, v.21, n.202, p.127-130, 2000. Available from: <http:/www.epamig.br/index.php?option=com docman\&task $=$ cat_view\&gid $=141 \&$ dir $=$ DESC\&order $=$ date \&limi $\mathrm{t}=10 \&$ limitstart $=20>$. Accessed: June 12, 2013.

GALDIANO JÚNIOR, R.F. et al. In vitro growth and acclimatization of Cattleya loddigesii Lindley (Orchidaceae) with active charcoal in two light spectra. Ciência Rural, Santa Maria, v.42, n.5, p.801-807, 2012. Available from: <http://www.scielo.br/ pdf/cr/v42n5/a13212cr5881.pdf>. Accessed: May 24, 2013.

GALDIANO JÚNIOR, R.F. et al. Sucrose concentrations in in vitro development and acclimatization of Cattleya loddigesii Lindley. Semina: Ciências Agrárias, Londrina, v.34, n.2, p.583592, 2013. Available from: $<$ http://www.uel.br/revistas/uel/index. $\mathrm{php} / \mathrm{semagrarias} /$ article/view/9514/pdf $>$. Accessed: May 24, 2013.

GNASEKARAN, P. et al. Effects of complex organic additives on improving the growth of PLBs of Vanda Kasem's Delight. Australian Journal of Crop Science, Australia, v.6, n.8, p.1245-1248, 2012. Available from: <http://www.cropj.com/ subramaniam\%281989\%29_6_8_2012_1245_1248.pdf $>$. Accessed: May 24, 2013.

FIGUEIREDO, M.A. et al. Variações no meio de cultura sobre o crescimento in vitro em híbridos de orquídea. Revista Brasileira de Biociências, Porto Alegre, v.5, n.2, p.294-296, 2007. Available from: $<$ http://www.ufrgs.br/seerbio/ojs/index.php/rbb/article/view/278>. Accessed: Jul. 05, 2012.

KÄMPF, A.N. Produção comercial de plantas ornamentais. Guaíba, RS: Agropecuária, 2000. 254p.

KANECHI, M. et al. The effects of carbon dioxide enrichment, natural ventilation, and light intensity on growth, photosynthesis, and transpiration of cauliflower plantlets cultured in vitro photoautotrophically and photomixotrophically. Journal of American Society for Horticultural Science, Alexandria, v.123, n.2, p.176-181, 1998. Available from: <http://journal. ashspublications.org/content/123/2/176.full.pdf $>$. Accessed: Sept. $14,2012$.

MAHENDRAN, G. et al. Asymbiotic seed germination of Cymbidium bicolor Lindl. (Orchidaceae) and the influence of mycorrhizal fungus on seedling development. Acta Physiologiae Plantarum, Poland, v.35, p.829-840, 2013. Available from: $<$ http://www.researchgate.net/publication/235788411 Asymbiotic_seed_germination_of_Cymbidium_bicolor_ Lindl. \%280rchidaceae $\% 29$ and the influence of mycorrhizal fungus_on_seedling_development $>$. Accessed: $\overline{\text { May }}$ 27, 2013. do $\bar{i}$ 10.1007/s11738-012-1127-3.

MURASHIGE, T.; SKOOG, F. A revised medium for rapid growth and biossays with tabacco tissue cultures. Physiologia Plantarum, Weinheim, v.15, n.3, p.473-497, 1962. Available from: <http:// onlinelibrary.wiley.com/doi/10.1111/j.1399-3054.1962.tb08052.x/ abstract> . Accessed: Oct. 30, 2012. doi:10.1111/j.1399-3054.1962. tb08052.x.

PARK, S.W. et al. Effect of sealed and vented gaseous microenvironments on the hyperhydricity of potato shoots in vitro. Scientia Horticulturae, Amsterdam, v.99, n.2, p.199-205, 2004. Available from: $<$ http://www.sciencedirect.com/science/article/pii/ S0304423803000979>. Accessed: Nov. 15, 2012. doi: 10.1016/ S0304-4238(03)00097-9.

PRIZÃO, E.C. et al. Activated charcoal and graphite for the micropropagation of Cattleya bicolor Lindl. and a orchid double-hybrid 'BLC Pastoral Innocence'. Acta Scientiarum. Agronomy, Maringá, v.34, n.2, p.157-161, 2012. Available from: <http://periodicos.uem.br/ ojs/index.php/ActaSciAgron/article/view/12257/pdf> . Accessed: Jan. 17, 2013. doi: 10.4025/actasciagron.v34i2.12257.

STANCATO, G.C. et al. Crescimento de orquídeas epífitas in vitro: adição de polpa de frutos. Bragantia, Campinas, v.67, n.1, p.51-57, 2008. Available from: <http://www.scielo.br/pdf/brag/ v67n1/a06v67n1.pdf>. Accessed: Jun. 15, 2012.

SUTTLEWORTH, F.S. et al. Orquídeas: guia dos orquidófilos. Rio de Janeiro: Expressão e Cultura, 1994. 158p.

THOMAS, T.D. The role of activated charcoal in plant tissue culture. Biotechnology Advances, v.26, p.618-631, 2008. Available from: $<$ http://www.sciencedirect.com/science/article/pii/ S0734975008000864>. Accessed: May 24, 2013. doi:10.1016/j. biotechadv.2008.08.003.

ULLMANN, H.F. Botanica's pocket orchids: over 1200 species listed. Australia: Random House Australia Pty, 2007. 608p.

WILlIAMS, N.H. Taxonomy of the genus Aspasia Lindley (Orchidaceae: Oncidieae). Brittonia, New York, v.6, n.4, p.333346, 1974. Available from: <http:// www.jstor.org/stable/2805817>. Accessed: May 27, 2013. 